\title{
The Notion of Non-Equivalent Vocabulary in Linguistics
}

\author{
Zokirova Sohiba Mukhtoraliyevna
}

Yasmina-taj@rambler.ru

\begin{abstract}
The article defines some thoughts according to the notion of non-equivalence vocabulary. The data due to non- equivalence vocabulary is acknowledged by Uzbek, Russian, English examples. Also the ideas of certain scientist are provided.
\end{abstract}

Keywords: non-equivalence vocabulary, lacuna, lacunas unit, referentially - non equivalence vocabulary, pragmatic - non equivalence vocabulary, alternative - non equivalence vocabulary.

\section{INTRODUCTION}

Significant rise of the interest related with following reasons: need to identify universal features of language material desire to describe world picture of different language speakers; need to improving bilingual dictionaries where national-specific features of semantics translated conformity is specified, interest to study national semantic specificity and study national specificity of language thinking, increase interest in the linguistic consciousness of native speakers and desire to describe group, social, gender, age and other features of language and etc...

\section{Materials AND Methods}

Particularly traditional-descriptive method is used in this research. Following general linguistic method are served as methodological bases of our investigation:

- Synchronously-descriptive method, which lets refer to languages with different structures,

- Contrastive method, which lets to analyze and to describe lexical units, reveal general and peculiar things in investigated languages.

Moreover we used some notions of linguistic typology and linguistic universal.

Materials of investigation have been taken from different genres and art style, newspaper publicist and popular science texts.

\section{RESULTS AND DISCUSSION}

The history of every language gives evidence of constant changes of vocabulary according to rapid modifications of the life of society with the development of production, culture, science.

Distinction between languages provided by cultural difference is noticeable in vocabulary and phraseology because the nominative means of language linked directly with extra linguistic reality. There are some words in any language which have no one-word translation in other languages.

This is so-called non-equivalent lexis particularly denotation specific notions of local culture [5.p 52]. In the language vocabulary of any nation there are some words with specific national-cultural meaning, which reflect referents inherent to only one particular nation and absent in nation-speaker of comparing language. For example: name of meals of national cuisine/ Rus. Борщ, щи, квас: UzbPlov, beshbarmoq, sumalak); national clothes/ Rus. Сарафaн, Uzb. Chopon, belbog') and etc. They reflect typical reality of certain country, certain nation and certain culture and do not have conformity in the consistently of other languages accordingly, their lexical notions have national-cultural specifics. We can conclude that semantics of words with national-cultural specifics are peculiar "mirror" of national culture and reflect Features and trends of the language system development. [3.p. 157.158] National-cultural specifics of semantics of words. We differ from national-language originality which does not concern to the cultural features. V. Gladrov stress that "It is necessary to 
differ names of realias from names which have no equivalent correspondence in comparing language spite of corresponding denotat' [8.p. 15]. For example There is no lexical unit in Uzbek language corresponding to English meaning drugstore and in English language there is no lexical unit with corresponding meaning to Uzbek corresponding пахта туйи "holiday on harvest occasion' These Kind of lexical unit L.S.Barhudarov calls' random lacunas, [1.p 95] V.L.Muravyev - "absolute linguistic lacunas" [6.p 8] I.A.Sternin - "unmotivated lacunas"[7.p 31].

Distinction of the notion "lacunar unit" and "lacuna" excludes synonymization of the notion "lacunar unit" and non equivalent unit. As we can see, the word of the language A can be lacunar correlating with lacuna of the language B and at the same time has an equivalent in this language. For example, an English word finger has an equivalent бармоқ in Uzbek language, in Russian language - палец, in Tadjik - ангуші, but at the same time it is lacunar because the notion finger and toe is not differentiated in Uzbek, Russian and Tadjik languages.

See also, Uzbek ko'k covers the meaning of three words - голубой/ blue), синий/dark blue), зелёный/green). Two Uzbek words - tush and hayol corresponded to the English word dream, Russian words пахнуть and нюхать corresponded to English smell etc.

The notion of lacunar unit and non - equivalent unit is not synonymous because lacunar unit as a language unit has level characteristics. That's why level classification of lacunar units are lingvema, (morpheme, lexeme, frazema ...) of one unit correlating with lacunas (zeros, white dots, gaps) of another language and lacunarity is manifested in all levels of the language.

As Researchers indicate (I.M.Vereshagin, V.G.Kostomarov and others), that in order to establish availability of national - cultural specifics of meaning of a word can be done through comparison the semantics of words of two languages (or more). Comparative Researches of languages showed that national - cultural differences appeare especially on the lexical - phraseological levels.

A number of researchers agree that in Translation studying of non - equivalent vocabulary is linked with the notion of "transferability" and "equivalent", with the problem of non-equivalent and vocabulary translation means which denotes items or phenomena of national culture.

Famous scientists of the Field of translation such as L.S.Barhudarov, S.Vlakov, S.Florin, V.N.Komissarov, Ya.I.Resker, V.L.Rossels, G.V.Shatkov, A.V.Fedorov, A.D.Shveysarov, G.V.Chernov, A.O.Ivanov and others did significant contribution to the development of this issue.

Differences in modern linguistics, linguistic theory of translation, ethno linguistics, ethno psycholinguistics, contrastive linguistics, theory of intercultural communication mismatching between languages and cultures fixed in different language levels are described with different terms by authors. So words denoting notion, items, phenomena which are typical only for certain language collective and not having analogue in another language are defined with following terms: "non-equivalent vocabulary" (L.S.Barhudarov, E.M.Vereshagin, V.G.Kostomarov), "realiz", "exoticisms" (S.Vlahov, S.Florin) "xenonims" (V.V.Kabakchi), "logoepistemes" (E.Yu.Prohorov), "lacuna" (I.A.Sterkin, V.L.Muravev) and others.

Exactly this kind of language units make national - cultural content of initial language text and represent ethno semantic level difficulties which recipient faces in intercultural communication. From the point of view by F.M.Vereshogina and V.G.Kostomrova, non-equivalent vocabulary - these are words which cannot be semantic with the assistance of translation (they have no sustainable compliance in other languages, they have no notional compliance in the content system, particular to other languages) "words, plan of content which cannot be compared with any other foreign language vocabulary notions. That's why the notion of "non-equivalent vocabulary", involve not only absence of equivalent but also the reson of this certain absence - "reflection with specific material and spiritual culture words. [2.p. 138]

National - cultural component of non-equivalent vocabulary being semantic heterogeneous micro component find its expression in semantic structure of a word by obligatory sem "locality", "ethnic accessory" and optional sem "historical relatedness", "social-political activities", "socio-cultural information", "confessional accessory".

On this basis, that words which have no notional correspondence in the content system inherent to another language can be accepted as non-equivalent vocabulary. 
Their existing is explained by cultural difference, and the question of the boundaries of this group has been controversial so far.

Classification of non-equivalent vocabulary can be conducted by genetic trait.

1. Word of life (all neologisms)

2. Names of items and phenomena's of traditional life.

3. Historicisms

4. Lexis of phrasedogical units

5. Folklore words

6. Slang words / youth slang, criminal slang, military slang, any professional slang

7. Social - political vocabulary

8. Reduced, colloquial vocabulary

A.O.Ivanov divides all nonequivalent vocabulary into three big groups.

1. Referentially - nonequivalent, which includes term, individual (author), neologisms, semantic lacunas, words of wide semantics, complex words;

2. Pragmatically - nonequivalent, uniting abnormalities, foreign inclusions, abbreviations, words with suffixes of subjective evolution, interjections, imitation a sound and associative lacunas;

3. Alternatively - nonequivalent vocabulary including proper names, circulation, realia and phraseologisms. [4.p. 46]

\section{Conclusions}

In conclusion, nonequivalent vocabulary is treated very wide from the point of availability of translation equivalent, that's why the number of nonequivalent words contains lexical units with national - cultural and lingua national peculiarities.

\section{REFERENCES}

[1] Бархударов Л.С. Язык и перевод: вопросы общей и частной теории перевода - М.: Академия, 2004. - 237c.

[2] Верещагин Е.М. Язык и культура. - М. : Русский язык, 1990. - 387 с.

[3] Зубкова Л.И. Лингвострановедческий подход в изучении национально-культурной специфики слова // Научно-методический сборник. - Воронеж, 1993. №43. - С. 157-158.

[4] Иванов А.О. Безэквивалентная лексика. - Спб.: Союз, 2007, - 256с.

[5] Мечковская, Н.Б. Социальная лингвистика. - М.: аспект Пресс, 2006. - 206c.

[6] Муравьёв В.Л. Лексические лакуны (на материале лексики французского и русского языков). - Владимир, 1975.

[7] Стернин И.А. Контрастивная лингвистика. - М.: Восток-запад, 2006. - 206с.

[8] Gladrow, W. Russischim Spiegelndes Deutschen / W. Gladrow. - Wien : Lang, 1998. - 271 S. 